\title{
Evaluation of growth and production of Pleurotus sp. in sterilized substrates
}

\author{
Avaliação do crescimento e da produção de Pleurotus sp. em substratos \\ esterilizados
}

Eduardo Bernardi ${ }^{*}$, Elisandra Minotto², José Soares do Nascimento ${ }^{3}$

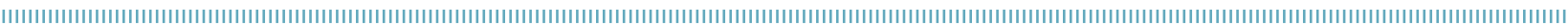

\begin{abstract}
The gender Pleurotus is also known as oyster mushroom, shimeji or hiratake. Aiming to select the best substrates to cultivate two species of Pleurotus, this work measured vigor, mycelium growth $\left(\mathrm{cm} \cdot \mathrm{day}^{-1}\right)$, fresh mass $(\mathrm{g})$, productivity (\%) and biological efficiency (\%) of P. sajor-caju (PSC96/03) and P. ostreatoroseus (POR01/06) cultivated in the following substrates: sugarcane bagasse, elephant grass, waste of castor oil plant and pasteurized rice straw. Fungal cultures were recovered in culture medium CDA. For the evaluation of mycelium growth, moist substrates were put into a closed assay tube with sterilized aluminum paper. Then, they were inoculated in $10 \mathrm{~mm}$ culture dishes and taken to the incubator at $26 \pm 2^{\circ} \mathrm{C}$. Mycelium vigor was measured with grades from 1 to 3 according to density. For axenic cultivation, substrates were placed into $250 \mathrm{~g}$ flasks of substrate and autoclaved twice at $121^{\circ} \mathrm{C}(1 \mathrm{~atm})$ for 60 minutes, and then inoculated with $3 \%$ of spawn. The lineage P. sajor-caju (PSC96/03) showed higher growth rates in relation to $P$. ostreatoroseus (POR01/06). Substrates showing lower C/N ratio provided more mycelium vigor. Castor oil plant waste based-substrate showed good perspectives to growing P. sajor-caju (PSC96/03).
\end{abstract}

KEYWORDS: Pleurotus; castor oil plant; substrates; biological efficiency; productivity.
RESUMO: O gênero Pleurotus é conhecido como cogumelo ostra, shimeji ou hiratake. Neste trabalho, com a finalidade de selecionar substratos para o cultivo de duas espécies de Pleurotus, foram avaliados vigor, crescimento micelial $\left(\mathrm{cm} \cdot \mathrm{dia}^{-1}\right)$, massa fresca $(\mathrm{g})$, produtividade (\%) e eficiência biológica (\%) de P. sajor-caju (PSC96/03) e P. ostreatoroseus (POR01/06) cultivados nos substratos: bagaço de cana-de-açúcar, capim-elefante, resíduos da cultura da mamona e palha de arroz esterilizados. As culturas fúngicas foram recuperadas em meio de cultura CDA. Para avaliar o crescimento micelial, os substratos úmidos foram acondicionados em tubos de ensaio e fechados com papel alumínio esterilizados. Depois, foram inoculados com discos de cultura de $10 \mathrm{~mm}$ de diâmetro e incubados em estufa a $26 \pm 2^{\circ} \mathrm{C}$. O vigor do micélio foi mensurado por meio de notas de 1 a 3, conforme adensamento. Para o cultivo axênico, os substratos foram colocados em frascos de $250 \mathrm{~g}$ de substrato e autoclavados duas vezes a $121^{\circ} \mathrm{C}$ (1 atm) por 60 minutos, posteriormente inoculados com 3\% de spawn . Ao serem analisadas, a linhagem P. sajor-caju (PSC96/03) apresentou maior velocidade de crescimento que a P. ostreatoroseus (POR01/06), os substratos com menor relação $\mathrm{C} / \mathrm{N}$ propiciaram maior vigor de micélio e o substrato à base de resíduos da cultura da mamona apresentou perspectivas para o cultivo de P. sajor-caju (PSC96/03).

PALAVRAS-CHAVE: Pleurotus; mamona; substratos; eficiência biológica; produtividade.

\footnotetext{
${ }^{1}$ Instituto de Biologia da Universidade Federal de Pelotas (UFPEL) - Pelotas (RS), Brazil.

${ }^{2}$ Universidade Federal do Rio Grande do Sul (UFRGS) - Porto Alegre (RS), Brazil.

${ }^{3}$ Universidade Federal da Paraíba (UFPB) - João Pessoa (PB), Brazil.

*Corresponding author: bernardieduardo@yahoo.com.br

Received on: 06/09/2011. Accepted on: 02/07/2013
} 


\section{INTRODUCTION}

The growth stage of fungal mycelium in the substrate is very important for mushroom production, since a suitable substrate facilitates mycelium colonization and avoids risks of contamination later on, mainly by other fungi and bacteria that can affect the production (Royse, 2002). Most edible mushrooms have high index of mycelium development on different kinds of prime matter. So, the selection of a substrate is indispensable for the mycelium to develop fast, with vigor, and to enhance mushroom production.

Edible mushrooms adapted to tropical regions require climatic conditions such as temperature oscillating around 25 and $30^{\circ} \mathrm{C}$ at the growth stage of the mycelium. Abrupt temperature variations lead to growth stagnation and, in some cases, when temperature reaches values above the limit of in vitro growth, $34^{\circ} \mathrm{C}$, it may cause mycelium inactivation (Nascimento; Eira, 2003). Under semicontrolled cultivation, lineages that are not adapted to the climate of the place they are cultivated will not show satisfactory mycelium growth and mushroom production (Rossi et al., 2001).

The fungi of the gender Pleurotus are edible mushrooms with high nutritional value, easy growing regarding substrate and with good development under rustic conditions (Sснмidt et al., 2003). It is easily cultivated in a great variety of agricultural residues, such as straws, grass, sawdust, coconut husk, corncob, sugarcane bagasse, and others of organic nature (Donini et al., 2005; Donini et al., 2009). This excellent development is due to the production of some lignocellulosic enzymes that allow the easy degradation of the lignin and cellulose of the wood, as well as other plant substrates used for this particular cultivation (Capelari, 1996).

Оводаг et al. (2003) recommend the use of different lignocellulosic products, such as rice straw, banana leaves, elephant grass and sawdust to cultivate Pleurotus ostreatus. Hernández et al. (2003) used compounds based on grass and coffee mass to prepare the substrate to cultivate that mushroom. However, SAGIR; YILDIZ (2004) reported a study on mycelium growth of five species of Pleurotus spp. in sorghum and wheat grains. According to Moda et al. (2005) a large amount of agricultural residues could be used to produce edible mushroom Pleurotus spp., such as those of sugarcane bagasse, corncob, banana leaves and cotton.

The inoculation of lignocellulose, such as Pleurotus spp., into agricultural residues is a significant option, because it represents an alternative to enable the use of these compounds without adding chemical products. This is a good option for biological treatments, since it reducing lignocellulosic materials; moreover, it turns up as an alternative to food and commercial production (Doelle, 1996; Kalmiş; SARGIN, 2004).
This work aimed to select a substrate among sugarcane bagasse, elephant grass, castor oil plant wastes and sterilized rice available in the region to cultivate Pleurotus sajor-caju (PSC96/03) and Pleurotus ostreatoroseus (POR01/06) through evaluations of vigor, in vitro mycelium growth, fresh mass, productivity and biological efficiency.

\section{MATERIALS AND METHODS}

The present work was divided into two experiments and carried out at the Mycology Laboratory of the Department of Microbiology and Parasitology in the Institute of Biology of Universidade Federal de Pelotas, RS.

The initial cultures were obtained from the lineages PSC96/03 Pleurotus sajor-caju and POR01/06 of Pleurotus ostreatoroseus, belonging to Módulo de Cogumelos FCA/ UNESP/Botucatu/SP and Laboratório Experimental de Micologia/IB/UFPel, respectively. Both lineages were deposited in the mycotech of the LEMICO/DEMP/IB/UFPel and preserved in mineral oil. Cultures were replicated to CDA culture medium made of elephant grass+dextrose+agar (Donini et al., 2005) and incubated at $28^{\circ} \mathrm{C}$ for 10 days until recovery.

To evaluate mycelium growth of the mushroom, four different substrates were used: sugarcane bagasse, elephant grass, castor oil plant waste, and rice husks. Substrates were previously moistened for 24 hours and put into a 2.5 x 20 $\mathrm{cm}$ assay tube. The bottom of each tube was filled with moist cotton and a $13 \mathrm{~cm}$ column of substrate. Tubes were identified according to treatment, closed with aluminum paper and autoclaved at $121^{\circ} \mathrm{C}(1 \mathrm{~atm})$ for 45 minutes.

Under laminar flow hood, culture dishes of $10 \mathrm{~mm}$ in diameter, previously prepared in culture medium CDA, were replicated to assay tubes containing substrate according to the treatment. The treatments consisted of $\mathrm{T} 1=$ elephant grass; $\mathrm{T} 2=$ sugarcane bagasse; $\mathrm{T} 3=$ rice husks; $\mathrm{T} 4=$ castor oil plant wastes; $\mathrm{T} 5=$ elephant grass + sugarcane bagasse (1:1); T6 = elephant grass + rice husk (1:1); T7 = elephant grass + castor oil plant wastes $(1: 1) ; \mathrm{T} 8=$ sugarcane bagasse + rice husk (1:1); T9 = sugarcane bagasse + castor oil plant wastes and T10 $=$ rice husks + castor oil plant wastes $(1: 1)$.

After inoculation, tubes were marked with four vertical lines to facilitate measurements, and then taken to an incubator at $26 \pm 2^{\circ} \mathrm{C}$. Evaluations were taken 48 hours after inoculation until the complete colonization of the substrate in some treatments. The evaluation of mycelium vigor was taken visually at the end of growth by ranking mycelium into grades 1 = weak mycelium, low density; 2 = medium mycelium, medium density, and 3 = strong mycelium, high density, according to Figure 1. 
The adopted experimental design was complete randomized. The experimental unity consisted of a tube with five replications/treatment. The results were submitted to Tukey's test for mean comparison and polynomial regression for the incubation period. The statistical software SANEST was used (Zonta; Machado, 1984).

For axenic cultivation, substrates were placed into $9 \mathrm{x}$ $16.8 \mathrm{~cm}$ flasks filled up to $13 \mathrm{~cm}$ of each treatment, which corresponded to $250 \mathrm{~g}$ of substrate. Flasks were identified, closed with aluminum paper and plastic film and then autoclaved twice at $121^{\circ} \mathrm{C}(1 \mathrm{~atm})$ for 60 minutes, with a 48 hour interval. Treatments were the same used for the evaluation of mycelium growth.

Under laminar flow hood, substrates were inoculated with $3 \%$ of mushroom seeds. Flasks were taken to an incubator $\left(26 \pm 2^{\circ} \mathrm{C}\right)$ until the complete colonization of most treatments. Afterwards, the aluminum paper was removed and flasks were transferred to fruiting camera under temperature conditions of $25 \pm 3^{\circ} \mathrm{C}$ and relative humidity of air of $75-90 \%$. Mushrooms resulting from a 45-day production were manually collected and weighed, obtaining data to fresh mass, productivity and biological efficiency, according to Bernardi et al. (2007). The obtained results were submitted to Tukey's test for comparison using the statistical software SANEST (Zonta; Machado, 1984).

Before the cultivation process, the analyses of carbon and total nitrogen of the substrates were carried at the Soil Department/FAEM/UFPel according to the Walkey-Black method for organic carbon and semimicro-Kjeldahl for nitrogen (Tedesco et al., 1995).

\section{RESULTS AND DISCUSSION}

For mycelium growth and vigor, lineages were cultivated for 360 hours ( 15 days) at $26 \pm 2^{\circ} \mathrm{C}$. Mycelium growth was complete in some of the treatments after the aforementioned period. The lineage PSC96/03 of P. sajor-caju showed the highest growth rates during the incubation period (Table 1).

Considering the treatments used in this work, each lineage showed a different behavior. The highest growth rate of P. sajor-caju (PSC96/03) was observed in Treatment 10 (rice husks + castor oil plant wastes) after 48 hours of incubation, in Treatment 6 (elephant grass + rice husk) after 120 hours, in Treatment 3 (rice husk) after 168 and 216 hours. However, until the end of the incubation period, which lasted 264, 312 and 360 hours, the highest growth rate was seen in Treatment 6 . Species of $P$. ostreatoroseus (POR01/06) showed a different behavior when compared to P. sajor-caju (PSC96/03), since 48 hours after incubation the highest growth rate was observed in Treatment 1 (elephant grass); after 120 hours, the highest rate was visualized in Treatment 7 (elephant grass + castor oil plant wastes); and from 168 hours to the end of the incubation period (360 hours), growth in Treatment 1 was superior to the others in all evaluations, as seen in Table 2. In short, despite the growth variation during incubation time, the more suitable substrate for the lineage PSC96/03 was elephant grass + rice husk, and for the lineage POR01/06 elephant grass.

The growth rate according to each treatment (Figure 2) is linear in most cases, except for P. ostreatoroseus (POR01/06), in which Treatments 2, 3, 5, 8, 9 and 10 showed a quadratic growth curve. The differences in mycelium growth can be explained by the carbon and nitrogen ratio $(\mathrm{C} / \mathrm{N})$ in the substrates, as well as by the nutritional demands of each species or lineage of the mushroom used for cultivation. For the species P. sajor-caju (PSC96/03), the highest growth rate was mainly observed in Treatment 6 (elephant grass + rice husk, 1:1) which showed a $\mathrm{C} / \mathrm{N}$ ratio of 102:1 (Table 3). However, the lineage POR01/06 de P. ostreatoroseus had the highest growth rates during cultivation in Treatment 1 (elephant grass), with $\mathrm{C} / \mathrm{N}$ ratio of 162:1. According to STURION (1994), during micellization, a higher $\mathrm{C} / \mathrm{N}$ ratio is
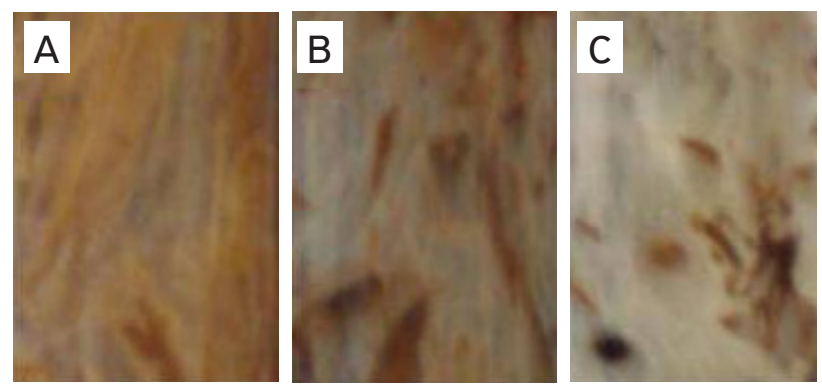

Figure 1. Parameters used in the attribution of grades for the mycelium vigor of species of Pleurotus cultivated under different substrates. (A) 1 = weak mycelium, low density; 2 = medium mycelium, medium density; 3 = strong mycelium, high density.

Table 1. Mycelium growth (cm) of Pleurotus sajor-caju (PSC96/03) and Pleurotus ostreatoroseus (PORO1/06) under different substrates, after 360 hours ( 15 days) of incubation at $26 \pm 2{ }^{\circ} \mathrm{C}$.

\begin{tabular}{lccccccc} 
Strains & \multicolumn{7}{c}{ Incubation time (hours) } \\
\cline { 2 - 9 } & 48 & 120 & 168 & 216 & 264 & 312 & 360 \\
\hline PSC 96/O3 & $0.82^{\mathrm{aG}}$ & $2.89^{\mathrm{aF}}$ & $4.49^{\mathrm{aE}}$ & $6.18^{\mathrm{aD}}$ & $7.99^{\mathrm{aC}}$ & $9.71^{\mathrm{aB}}$ & $11.58^{\mathrm{aA}}$ \\
\hline POR 01/O6 & $0.01^{\mathrm{bG}}$ & $1.08^{\mathrm{bF}}$ & $2.28^{\mathrm{bE}}$ & $3.86^{\mathrm{bD}}$ & $5.42^{\mathrm{bC}}$ & $6.94^{\mathrm{bB}}$ & $8.75^{\mathrm{bA}}$ \\
\hline
\end{tabular}

Means followed by different uppercase letters in line and lowercase in column are significantly different by the Tukey's test $(\alpha=0.05)$. 
Table 2. Mycelium growth (cm) of Pleurotus sajor-caju (PSC96/03) and Pleurotus ostreatoroseus (PORO1/06) under different substrates during incubation period of 360 hours ( 15 days) at $26 \pm 2^{\circ} \mathrm{C}$.

\begin{tabular}{|c|c|c|c|c|c|c|c|c|c|c|c|}
\hline \multirow{2}{*}{$\frac{\frac{5}{d}}{\frac{0}{n}}$} & \multirow{2}{*}{ 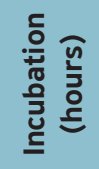 } & \multicolumn{10}{|c|}{ Treatments } \\
\hline & & T1 & T2 & T3 & T4 & T5 & T6 & T7 & T8 & T9 & $\mathrm{T} 10$ \\
\hline \multirow{7}{*}{$\begin{array}{l}\text { o } \\
\text { o } \\
\text { ù } \\
\text { ֻ }\end{array}$} & 48 & $0.76^{\mathrm{hM}}$ & $0.62^{\mathrm{jL}}$ & $0.66^{\mathrm{im}}$ & $0.78^{\mathrm{gM}}$ & $0.92^{\mathrm{bM}}$ & $0.86^{d M}$ & $0.90^{\mathrm{cm}}$ & $0.82^{f L}$ & $0.84^{\mathrm{eM}}$ & $1.00^{\mathrm{aL}}$ \\
\hline & 120 & $2.98^{\mathrm{eJ}}$ & $2.06^{\mathrm{jJ}}$ & $3.10^{c J}$ & $3.02^{\mathrm{dJ}}$ & $2.90^{\mathrm{gJ}}$ & $3.32^{\mathrm{aJ}}$ & $2.92^{\mathrm{fJ}}$ & $2.72^{\mathrm{iJ}}$ & $2.88^{\mathrm{hJ}}$ & $3.22^{\mathrm{bJ}}$ \\
\hline & 168 & $4.52^{f l}$ & $3.32^{\mathrm{jH}}$ & $4.96^{\mathrm{aH}}$ & $4.56^{\mathrm{eH}}$ & $4.48^{\mathrm{gH}}$ & $4.92^{\mathrm{bH}}$ & $4.74^{\mathrm{dH}}$ & $4.16^{\mathrm{iH}}$ & $4.38^{\mathrm{hH}}$ & $4.86^{\mathrm{cH}}$ \\
\hline & 216 & $6.32^{\mathrm{eG}}$ & $4.82^{\mathrm{jE}}$ & $6.90^{\mathrm{aF}}$ & $6.20^{\mathrm{gF}}$ & $6.28^{f F}$ & $6.42^{\mathrm{dF}}$ & $6.58^{\mathrm{cF}}$ & $5.90^{\mathrm{hE}}$ & $5.88^{\mathrm{iF}}$ & $6.60^{\mathrm{bF}}$ \\
\hline & 264 & $8.06^{\mathrm{EE}}$ & $6.42^{\mathrm{jc}}$ & $8.82^{\mathrm{bD}}$ & $7.90^{\mathrm{gD}}$ & $8.04^{f D}$ & $8.88^{\mathrm{aD}}$ & $8.50^{C D}$ & $7.56^{\mathrm{hc}}$ & $7.46^{\mathrm{CD}}$ & $8.34^{d D}$ \\
\hline & 312 & $9.78^{\mathrm{fc}}$ & $7.94^{\mathrm{B}}$ & $10.68^{\mathrm{bB}}$ & $9.56^{9 B}$ & $9.88^{\mathrm{eB}}$ & $10.76^{a B}$ & $10.36^{\mathrm{cB}}$ & $9.26^{\mathrm{hB}}$ & $8.98^{\mathrm{B}}$ & $10.04^{\mathrm{dB}}$ \\
\hline & 360 & $11.62^{\mathrm{eA}}$ & $9.60^{\mathrm{iA}}$ & $12.80^{\mathrm{bA}}$ & $11.36^{\mathrm{gA}}$ & $11.53^{\mathrm{fA}}$ & $12.83^{\mathrm{aA}}$ & $12.35^{\mathrm{cA}}$ & $11.10^{\mathrm{hA}}$ & $10.70^{\mathrm{iA}}$ & $11.96^{\mathrm{dA}}$ \\
\hline \multirow{7}{*}{ 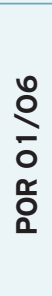 } & 48 & $0.12^{\mathrm{aN}}$ & $0.00^{\mathrm{bN}}$ & $0.00^{\mathrm{bN}}$ & $0.00^{\mathrm{bN}}$ & $0.00^{\mathrm{bN}}$ & $0.00^{\mathrm{bN}}$ & $0.00^{\mathrm{bN}}$ & $0.00^{\mathrm{bN}}$ & $0.00^{\mathrm{bN}}$ & $0.00^{\mathrm{bN}}$ \\
\hline & 120 & $1.50^{\mathrm{bL}}$ & $0.38^{\mathrm{jM}}$ & $1.10^{\mathrm{eL}}$ & $1.22^{\mathrm{dL}}$ & $0.96^{h L}$ & $1.34^{\mathrm{cL}}$ & $1.56^{\mathrm{aL}}$ & $0.74^{\mathrm{iM}}$ & $1.04^{\mathrm{fL}}$ & $0.98^{\mathrm{gM}}$ \\
\hline & 168 & $2.94^{\mathrm{aK}}$ & $1.16^{\mathrm{jK}}$ & $2.40^{\mathrm{eK}}$ & $2.52^{\mathrm{dK}}$ & $1.98^{\mathrm{hK}}$ & $2.62^{\mathrm{ck}}$ & $2.84^{\mathrm{bK}}$ & $1.70^{\mathrm{iK}}$ & $2.16^{g k}$ & $2.32^{\mathrm{fK}}$ \\
\hline & 216 & $4.90^{\mathrm{aH}}$ & $2.40^{j l}$ & $3.94^{f 1}$ & $4.24^{d l}$ & $3.50^{\mathrm{hl}}$ & $4.46^{c 1}$ & $4.64^{\mathrm{bl}}$ & $2.96^{i l}$ & $3.54^{g l}$ & $4.02^{\mathrm{el}}$ \\
\hline & 264 & $6.64^{\mathrm{aF}}$ & $3.60^{j 6}$ & $5.66^{\mathrm{eG}}$ & $5.84^{d G}$ & $5.12^{\mathrm{hG}}$ & $5.90^{\mathrm{cG}}$ & $6.40^{b G}$ & $4.22^{\mathrm{ig}}$ & $5.20^{g G}$ & $5.62^{\mathrm{fG}}$ \\
\hline & 312 & $8.32^{\mathrm{aD}}$ & $4.74^{\mathrm{jF}}$ & $7.36^{d E}$ & $7.40^{\mathrm{cE}}$ & $6.72^{\mathrm{hE}}$ & $7.32^{\mathrm{eE}}$ & $8.10^{\mathrm{bE}}$ & $5.46^{\mathrm{iF}}$ & $6.82^{\mathrm{gE}}$ & $7.20^{\mathrm{fE}}$ \\
\hline & 360 & $10.22^{\mathrm{aB}}$ & $6.14^{\mathrm{jD}}$ & $9.44^{c c}$ & $9.10^{\mathrm{ec}}$ & $8.58^{\mathrm{hc}}$ & $9.04^{\mathrm{fC}}$ & $9.89^{b c}$ & $7.12^{\mathrm{iD}}$ & $8.72^{g \mathrm{C}}$ & $9.24^{d C}$ \\
\hline
\end{tabular}

Means followed by different uppercase letters in line and lowercase in column are significantly different by the Tukey's test $(\alpha=0.05)$.

$\mathrm{T} 1$ = elephant grass; $\mathrm{T} 2$ = sugarcane bagasse; $\mathrm{T} 3$ = rice husks; $\mathrm{T} 4$ = castor oil plant wastes; $\mathrm{T} 5$ = elephant grass + sugarcane bagasse $(1: 1)$;

T6 = elephant grass + rice husk ( $1: 1) ; \mathrm{T} 7$ = elephant grass + castor oil plant wastes ( $1: 1) ;$ T8 = sugarcane bagasse + rice husk ( $1: 1)$;

T9 = sugarcane bagasse + castor oil plant wastes and T10 = rice husks + castor oil plant wastes $(1: 1)$.

necessary. FeLINTo (1999) evaluated the colonization rate of lineages L1 and L2 of P. ostreatus in different substrates and observed that those substrates elaborated with $50 \%$ cassava bran showed the lowest income, whereas substrate with no bran or with low concentration led to better results.

Diss et al. (2003) observed similar results when using pure substrate and bran-supplemented substrate in the cultivation of $P$. sajor-caju (Fr.) Singer; pure bean straw presented shorter mycelium growth time when compared to straw supplemented with $10 \%$ wheat bran. These authors associated this result to the existence of some excessive substance that might inhibit the mycelium growth of the fungi. MAIO (2003) used straw and rice bran in the cultivation of $P$. ostreatus (POS97/14) and observed that the increased concentration of rice bran from 10 to $20 \%$ led to decreased biological efficiency. The results of this work showed differences in mycelium growth and are supported by the results observed by BILAY et al. (2000), who noted that all 30 edible and medicinal mushroom species evaluated showed a particular mycelium growth, depending on the adopted culture medium. According to Stölzer; Grabbe (1991), growth rate is fundamental in the selection of lineages for mushroom production. This happens in the following stages, from colonization to production in the substrate, since lineages with higher growth rates will be first established, inhibiting the growth of other components of this environment.

Regarding mycelium vigor for both of the used species, Treatments 3, 4, 7, 9 and 10 for P. sajor-caju (PSC96/03) and
Treatments 4, 7, 9 and 10 for P. ostreatoroseus (POR01/06) showed the highest mycelium vigor (Table 3 ).

The highest vigor for both mushrooms are represented in the treatments in which the $\mathrm{C} / \mathrm{N}$ ratio is lower than, close and/or below to 100:1. According Donins et al. (2009), in poor nutritional substrates mycelium tends to grow faster in order to to compensate its nutritional requirements, thus becoming less vigorous. This fact is shown in this work with P. ostreatoroseus (POR01/06), which had higher growth rates in Treatment 1, however, with moderate mycelium vigor.

Based on the previously observed results, for the second phase of the experiment (th cultivation in production lines), the species P. sajor-caju (PSC96/03) was selected because it showed promising results. During the cultivation stage of $P$. sajor-caju (PSC96/03), the highest levels of fresh mass, productivity and biological efficiency were taken when the species was cultivated in Treatment 4 (substrate based on castor oil plant waste), however, they did not present statistical differences when compared with the results seen in Treatment 7 (elephant grass + castor oil plant wastes). The value of fresh mass was $43.79 \mathrm{~g}$ with biological efficiency and productivity of 52.55 and $17.52 \%$, respectively (Table 4).

The highest means of the analyzed variables in this stage of work were observed in the treatment of the lowest $\mathrm{C} / \mathrm{N}$ ratio, which is Treatment 4 (37:1). According to Eira; Minhoni (1997), the cultivation of mushroom of the gender Pleurotus provides better results in substrates with $\mathrm{C} / \mathrm{N}$ ratio of approximately $100: 1$, differently from the 

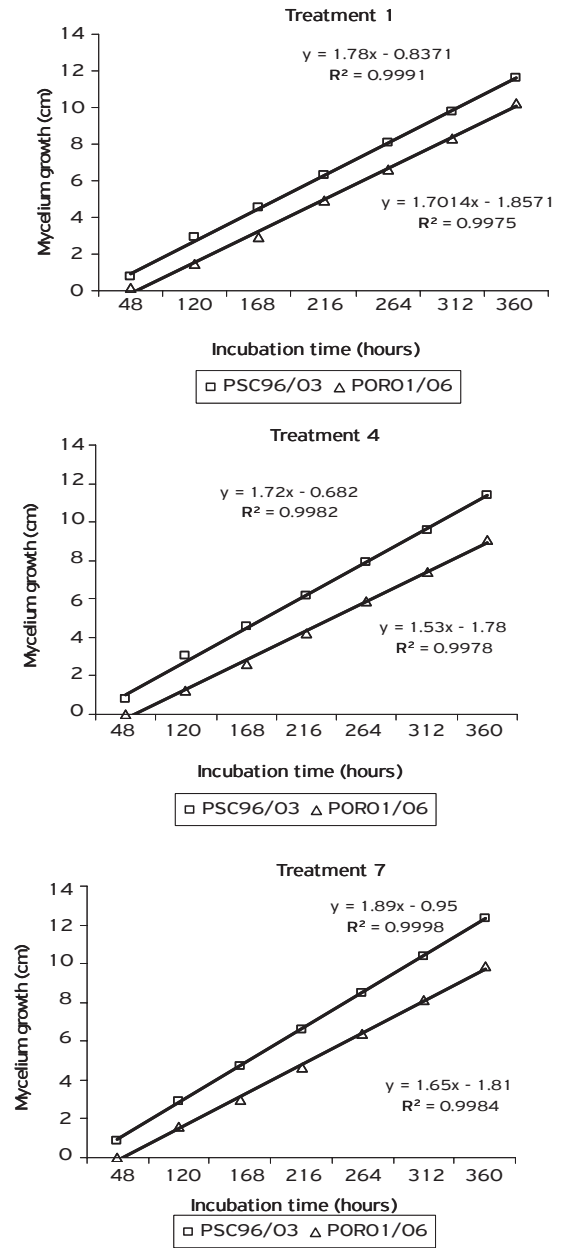

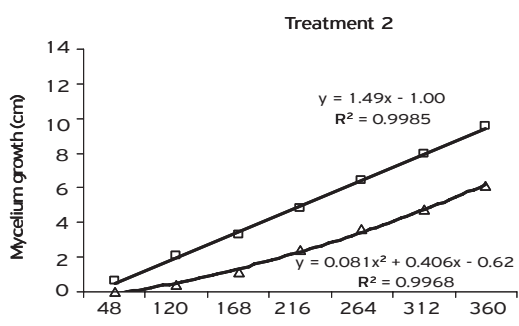

Incubation time (hours)
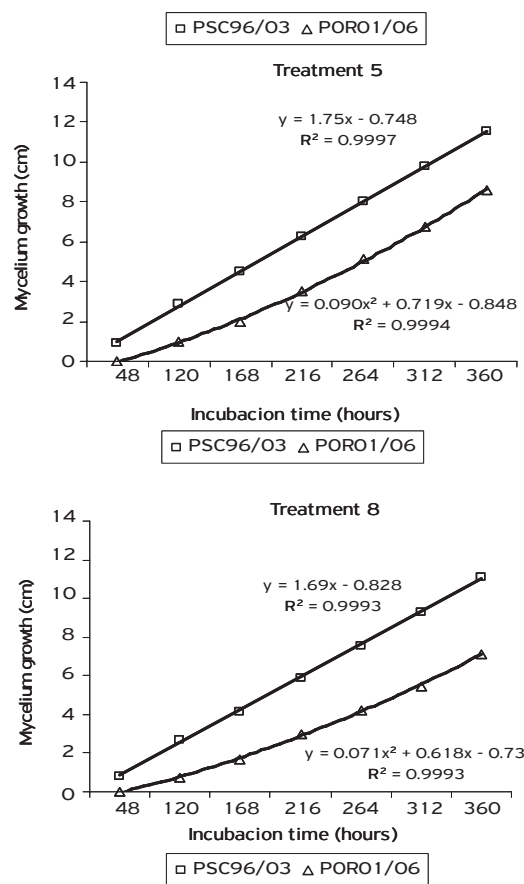
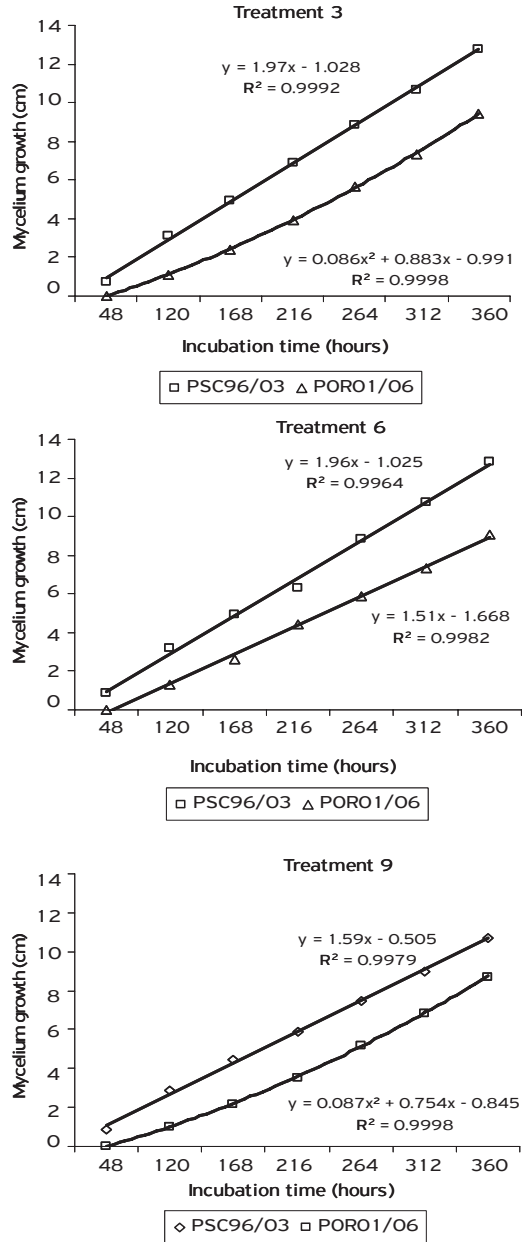

$\mathrm{T} 1$ = elephant grass; $\mathrm{T} 2$ = sugarcane bagasse; $\mathrm{T} 3$ = rice husks; $\mathrm{T} 4$ = castor oil plant wastes; $\mathrm{T} 5$ = elephant grass + sugarcane bagasse ( $1: 1$ ); T6 = elephant grass + rice husk $(1: 1) ;$ T7 = elephant grass + castor oil plant wastes $(1: 1)$; T8 = sugarcane bagasse + rice husk $(1: 1)$; T9 = sugarcane bagasse + castor oil plant wastes and T10 = rice husks + castor oil plant wastes (1:1).

Figure 2. Mycelium growth rate (cm.h-1) of Pleurotus sajor-caju (PSC96/03) and Pleurotus ostreatoroseus (PORO1/06) after 360 hours of incubation at $26 \pm 2^{\circ} \mathrm{C}$.

present results. Other different results are described by MaIO (2003), who observed decreased biological efficiency of the mushroom when substrate supplementation passed from 10 to $20 \%$ soybean bran. This supplementation may have led to a decreased C/N ratio. ModA et al. (2005) verified the same decreasing results in biological efficiency of P. sajor-caju when the supplementation of sugarcane bagasse with broken corn and mineral solution was adopted.

This adjustment in $\mathrm{C} / \mathrm{N}$ ratio to obtain better results could be performed in several ways, such as adding bran or mix with other substrates enriched with higher amount of nitrogen. Therefore, several works are described, such as the one by Dias et al. (2003), who cultivated P. sajor-caju in a substrate based on pure corn stover with $10 \%$ supplementation of wheat bran. They found a $51 \%$ biological efficiency using pure stover and an increase to $83 \%$ when using supplementation, corroborating the results of this work. Other similar results are also described by Donini et al. (2009), who studied the productivity and biological efficiency and observed that
Table 3. Mycelium vigor of Pleurotus sajor-caju (PSC96/03) and Pleurotus ostreatoroseus (PORO1/06) inoculated in different substrates.

\begin{tabular}{lccc} 
Treatments & $\begin{array}{c}\text { Relation } \\
\text { Carbon/ } \\
\text { Nitrogen }\end{array}$ & $\begin{array}{c}\text { Mushroom strains } \\
\text { P. sajor-caju } \\
\text { (PSC96/03) }\end{array}$ & $\begin{array}{c}\text { P. ostreatoroseus } \\
\text { (PORO1/06) }\end{array}$ \\
\hline T1 & $162: 1$ & $2.0^{\mathrm{aB}}$ & $2.0^{\mathrm{aB}}$ \\
\hline T2 & $143: 1$ & $1.0^{\mathrm{aC}}$ & $1.0^{\mathrm{aC}}$ \\
\hline T3 & $53: 1$ & $3.0^{\mathrm{aA}}$ & $2.0^{\mathrm{aB}}$ \\
\hline T4 & $37: 1$ & $3.0^{\mathrm{aA}}$ & $3.0^{\mathrm{aA}}$ \\
\hline T5 & $156: 1$ & $2.0^{\mathrm{aB}}$ & $2.0^{\mathrm{aB}}$ \\
\hline T6 & $102: 1$ & $3.0^{\mathrm{aA}}$ & $2.0^{\mathrm{aB}}$ \\
\hline T7 & $73: 1$ & $3.0^{\mathrm{aA}}$ & $3.0^{\mathrm{aA}}$ \\
\hline T8 & $93: 1$ & $2.0^{\mathrm{aB}}$ & $2.0^{\mathrm{aB}}$ \\
\hline T9 & $57: 1$ & $3.0^{\mathrm{aA}}$ & $3.0^{\mathrm{aA}}$ \\
\hline T10 & $44: 1$ & $3.0^{\mathrm{aA}}$ & $3.0^{\mathrm{aA}}$ \\
\hline
\end{tabular}

Means followed by different uppercase letters in line and lowercase in column are significantly different by the Tukey's test $(\alpha=0.05$ ). $\mathrm{T} 1$ = elephant grass; $\mathrm{T} 2$ = sugarcane bagasse; $\mathrm{T} 3$ = rice husks; T4 = castor oil plant wastes; T5 = elephant grass + sugarcane bagasse (1:1); T6 = elephant grass + rice husk (1:1); T7 = elephant grass + castor oil plant wastes $(1: 1) ;$; $8=$ sugarcane bagasse + rice husk $(1: 1)$; T9 = sugarcane bagasse + castor oil plant wastes and $\mathrm{T} 10=$ rice husks + castor oil plant wastes $(1: 1)$. 
Table 4. Fresh mass, biological efficiency and productivity of Pleurotus sajor-caju (PSC96/03) cultivated under different axenic substrates.

\begin{tabular}{|c|c|c|c|}
\hline \multirow{2}{*}{ Treatments } & \multicolumn{3}{|c|}{ Pleurotus sajor-caju (PSC96/03) } \\
\hline & Fresh mass $(g)$ & Biological efficiency (\%) & Productivity (\%) \\
\hline T1 & $15.55^{\text {de }}$ & $24.06^{\mathrm{cd}}$ & $6.22^{\mathrm{cd}}$ \\
\hline T2 & $4.43^{f}$ & $7.97^{\mathrm{e}}$ & $1.78^{\mathrm{e}}$ \\
\hline T3 & $21.70^{\mathrm{bcd}}$ & $34.72^{\mathrm{bc}}$ & $8.68^{\mathrm{cd}}$ \\
\hline T4 & $43.79^{a}$ & $52.55^{a}$ & $17.52^{\mathrm{a}}$ \\
\hline T5 & $13.16^{\text {de }}$ & $21.90^{\mathrm{cd}}$ & $5.26^{\text {cd }}$ \\
\hline T6 & $22.94^{\mathrm{bcd}}$ & $36.08^{\mathrm{bc}}$ & $9.17^{\mathrm{bc}}$ \\
\hline $\mathrm{T7}$ & $38.53^{\mathrm{ab}}$ & $52.06^{a}$ & $15.41^{\mathrm{ab}}$ \\
\hline T8 & $12.62^{\text {de }}$ & $21.38^{\mathrm{cd}}$ & $5.05^{\mathrm{cd}}$ \\
\hline T9 & $20.94^{\text {cd }}$ & $30.15^{b c}$ & $8.38^{\mathrm{cd}}$ \\
\hline T10 & $31.78^{b c}$ & $43.58^{b c}$ & $12.71^{\mathrm{bc}}$ \\
\hline
\end{tabular}

Means followed by the same lowercase in column are not different by the Tukey's test $(\alpha=0.05)$.

$\mathrm{T} 1$ = elephant grass; $\mathrm{T} 2$ = sugarcane bagasse; $\mathrm{T} 3$ = rice husks; $\mathrm{T} 4$ = castor oil plant wastes; $\mathrm{T} 5$ = elephant grass + sugarcane bagasse ( $1: 1)$; T6 = elephant grass + rice husk ( $1: 1) ; \mathrm{T} 7$ = elephant grass + castor oil plant wastes $(1: 1)$; 8 = sugarcane bagasse + rice husk $(1: 1)$; T9 = sugarcane bagasse + castor oil plant wastes and T10 = rice husks + castor oil plant wastes (1:1).

the addition of wheat, rice and corn bran in the concentrations of 10 and $20 \%$ to the elephant grass substrate decreased $\mathrm{C} / \mathrm{N}$ ratio to approximately 50-60:1. Thus, the analyzed variables were higher in the treatment with no bran addition $(0 \%)$ when cultivating lineages BF24, DF33 and HF9 of Pleurotus ostreatus.

A factor to consider in this paper is the toxic and allergenic potential of some components present in castor oil (SRINIVAS; NagaraJ, 2000). It immediately suggests that the mushrooms produced substrates should go through this analysis and evaluation before being launched to human or animal consumption.

\section{CONCLUSIONS}

The species P. sajor-caju (PSC96/03) had higher growth rates than the P. ostreatoroseus (POR01/06); Pleurotus sajor-caju (PSC96/03) showed higher mycelium growth in the substrate elephant grass + rice husk, whereas P. ostreatoroseus (POR01/06) showed the same behavior but in the elephant grass substrate; Substrates showing low $\mathrm{C} / \mathrm{N}$ ratio provide higher mycelium vigor; The mushroom P. sajor-caju (PSC96/03) showed higher values of fresh mass, productivity and biological efficiency. It may be indicated for cultivation in the substrate based on castor oil plant waste.

\section{REFERENCES}

BERNARDI, E.; DONINI, L.P.; MINOTTO, E.; NASCIMENTO, J.S. Cultivation of three Pleurotus (Jacq.: Fr.) P. Kumm. species on pasteurized elephant grass (Pennisetum purpureum) substrate. International Journal of Medicinal Mushrooms, v.9, n.3/4, p.373-378, 2007.

BILAY, V.T.; SOLOMKO, E.F.; BUCHALO, A.S. Growth of edible and medicinal mushrooms on commercial agar media. In: Van Griensven, L.J.L.D. (Ed.). Science and cultivation of edible fungi. Rotterdam: Balkema, 2000. p.779-782.

CAPELARI, M. Atividade biodegradadora e cultivo de três espécies comestíveis de basidiomicetos: Pleurotus sp. e Agrocybe perfecta (Rick) Sing. 1996. 154f. Tese (Doutorado em Botânica) - Instituto de Biociências, Universidade de São Paulo, São Paulo, 1996.

DIAS, E.S.; KOSHIKUMO, E.M.S.; SCHWAN, R.F; SILVA, R. Cultivo do cogumelo Pleurotus sajor-caju em diferentes resíduos agrícolas. Ciência e Agrotecnologia, v.27, n.6, p.1363-1369, 2003.
DOELLE, H.W. Joint venture capital investment for clean tecnologies and their problems in developing countries. World Journal Microbiology and Biotechnology, v.12, p.445-450, 1996.

DONINI, L.P.; BERNARDI, E.; MINOTTO, E.; NASCIMENTO, J.S. Cultivation of shimeji on elephant grass substrate supplemented with different kinds of bran. Scientia Agraria, v.10, n.1, p.6774, 2009.

DONINI, L.P.; BERNARDI, E.; MINOTTO, E.; NASCIMENTO, J.S. Desenvolvimento in vitro de Pleurotus sp. sob a influência de diferentes substratos e dextrose. Arquivos do Instituto Biológico, v.72, n.3, p.331-338, 2005.

EIRA, A.F.; MINHONI, M.T.A. Manual teórico-prático do cultivo de cogumelos comestíveis. 2.ed. Botucatu: Fundação de Estudos e Pesquisas Agrícolas e Florestais, 1997. 115p.

FELINTO, A.S. Cultivo de cogumelos comestíveis do gênero Pleurotus spp. em resíduos agroindustriais. 1999. 
77f. Dissertação (Mestrado em Ciência e Tecnologia de Alimentos) - Escola Superior de Agricultura Luiz de Queiroz, Piracicaba, 1999.

HERNÁNDEZ, D.; SANCHEZ, J.E.; YAMASAKI, K. A simple procedure for preparing substrate for Pleurotus ostreatus cultivation. Bioresource Technology, v.90, n.2, p.145-150, 2003.

KALMIS, E.; SARGIN, S. Cultivation of two Pleurotus species on wheat straw substrates containing olive mill waste water. International Biodeterioration \& Biodegradation, v.53, p.43-47, 2004.

MAIO, C.S.S. Influência da composição do substrato sobre o valor nutricional do cogumelo Pleurotus ostreatus e seu potencial na redução da hipercolesterolemia experimental. 2003. 88f. Dissertação (Mestrado em Engenharia e Ciências de Alimentos) - Departamento de Química, Rio Grande, 2003.

MODA, E.M.; HORII, J.; SPOTO, M.H.F. Edible mushroom Pleurotus sajor-caju production on washed and supplemented sugarcane bagasse. Scientia Agricola, v.62, p. 127-132, 2005.

NASCIMENTO, J.S., EIRA, A.F. Occurrence of false truffle (Diehliomyces microsporus Gilkey) and damage on the Himematsutake medicinal mushroom (Agaricus brasiliensis $\mathrm{S}$. Wasser et al.). International Journal of Medicinal Mushrooms, v.5, n. 1, p.87-94, 2003.

OBODAI, M.; CLELAND-OKINE, J.; VOWOTOR, K.A. Comparative study on the growth and yield of Pleurotus ostreatus mushroom on different lignocellulosic by-products. Journal of Industrial Microbiology \& Biotechnology, v.30, n.3, p. 146-149, 2003.

ROSSI, I.H.; MONTEIRO, A.C.; MACHADO, J.O. Desenvolvimento micelial de Lentinula edodes como efeito da profundidade e suplementação do substrato. Pesquisa Agropecuária Brasileira, v.36, n.6, p.887-891, 2001.
ROYSE, D.J. Influence of spawn rate and commercial delayed release nutrient levels on Pleurotus cornucopiae (oyster mushroom) yeld, size, and time to production. Applied Microbiology Biotechnology, v.58, p.527-531, 2002.

SAGIR, A.; YILDIZ, A. Growth of mycelium of Pleurotus spp. on different grains and determination of their competition with some contaminant fungi. Acta Alimentaria, v.33, n.2, p.249257, 2004.

SCHMIDT, P.; WECHSLER, F.S.; NASCIMENTO, J.S.; JUNIOR, F.M.V. Tratamento do feno de braquiária pelo fungo Pleurotus ostratus. Revista Brasileira de Zootecnia, v.32, n.6, p.18661871, 2003.

SRINIVAS, C.V.S.; NAGARAJ, G. Factor influencing ricin, the toxic protein in castor cake and its detoxification. Journal of the Oil Technology Association of India, v.32, n. 1, p.21-23, 2000.

STÖLZER, S.; GRABBE, K. Mechanisms of substrate selectivity in the cultivation of edible fungi. In.: MAHER, M.J. (Ed.). Science and cultivation of edible fungi. Rotterdam: Balkema, 1991. v.1, p.141-146.

STURION, G.L. Utilização da folha de bananeira como substrato para o cultivo de cogumelos comestíveis (Pleurotus spp.). 1994. 56f. Dissertação (Mestrado em Ciência e Tecnologia de Alimentos) - Escola Superior de Agricultura Luiz de Queiroz, Piracicaba, 1994.

TEDESCO, M.J.; GIANELLO, C.; BISSANI, C.A.; BOHNEN, H.; VOLKWEISS, S.J. Análises de solo, plantas e outros materiais (Boletim Técnico, 5) 2.ed. Departamento de Solos, Porto Alegre, 1995.

ZONTA, E.P.; MACHADO, A.A. SANEST - Sistema de Análise Estatística para Microcomputadores. Registrado na Secretaria Especial de Informática sob nº 066060 - categoria A. Pelotas, RS: Universidade Federal de Pelotas, 1984. 